\title{
3-D MAPPING OF MANTLE SUBSTRATE IN THE ZIMNY BEREG AREA, RUSSIA
}

\author{
Sergei Sablukov and Ludmila Sablukova \\ TsNIGRI, Moscow, Russia
}

\section{INTRODUCTION}

The Zimny Bereg kimberlite area is unique, both in its great diversity of igneous rock occurrences and in that the possibility exists of analyzing the relationships between various compositional peculiarities of local volcanics and compositional features of their mantle source. Two distinct kimberlite series of Zimny Bereg, namely, the Fe-Ti series and $\mathrm{Al}$ series kimberlites (Sablukov, 1990), differ in composition even stronger than Group 1 and Group 2 South African kimberlites. In addition, Zimni Bereg kimberlites differ in diamond morphology, with "Uralian-type" rounded diamonds sharply predominating in most kimberlite bodies of both series, except in the recently discovered Grib pipe (Verichev, 1999), where flat-faced octahedral diamonds are dominant (Sergeeva, 2000).

\section{CONSANGUINITY OF ZIMNY BEREG VOLCANITES}

Igneous rocks of the Zimny Bereg district, diversified as they are, appear to be members of a common magmatic family. All local volcanites occur close together as rock bodies of like size and morphology (diatremes with craters, sills and dikes), therewith having similar textural and structural characteristics. In addition, Zimny Bereg volcanites are all of nearly the same age and, lastly, they all show certain regularity in the distribution of their geochemical parameters and tectonic controls.

\section{Age}

Local igneous rocks (the both kimberlite series and basalts) were all dated based on diversified paleofloristic data from diatremal and crater rocks (Callixylon sp., Arhaeopteris sibirica Zal., Xenocladia cf. medullosina Arnold., Leptophleum sp.) at Late Devonian, i.e., as precisely as actually possible: $367 \pm 7$ Ma (Sablukov, 1987).

\section{Geochemical zoning}

The pattern of Ta distribution in igneous tock autoliths over the Zimni Bereg area is quite regular, with some elements of central-type symmetry. Ta isoconcentration lines form a well defined concentric pattern, with peak Ta concentrations in the central zone of the district and minimum values in its marginal zones. This agrees well with certain mineralogical peculiarities of igneous rocks. Indeed, Fe-Ti series kimberlites containing picroilmenite, which ids the main Ta concentrator in kimberlites (Ilupin et al., 1983), occur in the central part of the Zimny Bereg area, whereas ilmenite-free Al-series kimberlites and basalts occur in the marginal zones of the study area (Sablukov et al., 2002) (Figure 1).

\section{Tectonic (structural) controls.}

The distribution of volcanic bodies with widely varying rock composition in the Zimny Bereg area is markedly symmetric. In line with the main directions of global jointing, its pattern follows the tectonically controlled hydrographic outlines of the study area (the White Sea neck, the Dvina gulf, the Kuloy river), and passes symmetrically relative to the western cape of Zimny Bereg. This suggests that local eruptive bodies are all confined to the same structural controls which formed (or were renewed) during a common local tectonomagmatic activization cycle and, consequently, that the compositional diversity of local kimberlites is primarily due to diverse set and composition of mantle substrate rocks from which they formed.

To summarize, the spatiotemporal relationship and geological (structural) similarity of the Earth Hercynian Zimny Bereg igneous rocks appear to be evidence of their consanguinity. Reasoning from this, mantle substrate mapping could be performed both based on actual mantle rock fragments occurring in kimberlite pipes and based on compositional characteristics of the rocks making up the pipes themselves as these components of eruptive bodies reflect there compositional features of mantle rocks as of a common point in time.

\section{MANTLE SUBSTRATE TYPIFICATION FOR THE ZIMNY BEREG AREA}

Comprehensive compositional examination of Zimny Bereg kimberlites revealed that their petrographic, geochemical and mineralogical peculiarities perfectly correlate with the quantity and mineral composition of mantle xenoliths occurring in these rocks (Sablukov, 1990). This allows one to identify different types of local mantle substrate and to tentatively map the 
distribution of these substrate types in the Zimny Bereg are, involving, in addition, some compositional characteristics of the kimberlite varieties containing only single high-pressure mineral species. In general, we have identified two distinct types of Zimny Bereg mantle substrate, the difference between them being due to heterogeneity of mantle rocks themselves as well as to heterogeneous development of mantle metasomatism: (1) the homogeneous "dunite" substrate, and (2) the heterogeneous "eclogite-peridotite"

\section{The homogeneous "dunite" substrate.}

The ultramafic nodules are submitted only by rocks of the Mg-Al magmatic series (Marakushev, 1984). The set of mantle rocks is very limited, all of them being almost purely olivinic, essentially dunites with clinopyroxene, orthopyroxene, pyrope and chrome spinel present as minor accessory minerals. Lherzolites are rare, and harzburgites and orthopyroxenites are few. substrate.

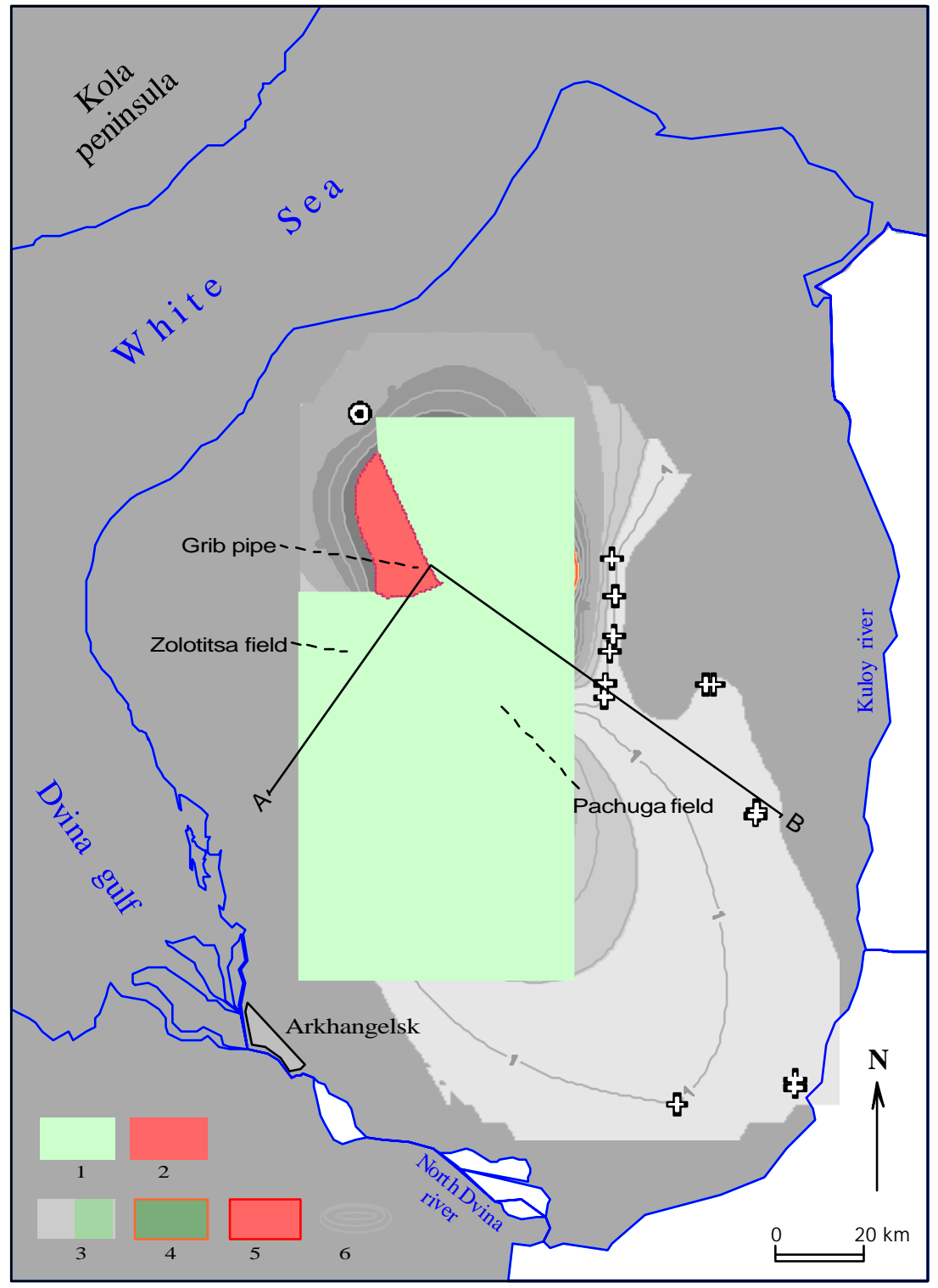

Figure 1. Distribution of various types of mantle substrates beneath the Zimny Bereg kimberlite areas.

1 - the zone of water-alkali (K-Na) mantle metasomatism; 2 - the zone of water-calc-alkali (K-Ca) mantle metasomatism; 3 - the homogeneous «dunite» mantle substrate; 4 - the heterogeneous «eclogite-peridotite» mantle substrate; 5 - the heterogeneous «eclogite-clinopyroxenite-peridotite» mantle substrate; 6 - isolines of Ta (trough $1 \mathrm{ppm}$ ) contents in the autoliths of the Zimny Bereg volcanic rocks. Circle shows the kimberlite rocks of the Al series, triangle shows the kimberlite rocks of the Fe-Ti series, cross shows the basalt rocks. A-B - line of the section, which shows on the Figure 2. 
Ultramafics are represented here by a complete rock series from diamond-pyrope D to spinel-pyroxene B depth facies (Sobolev et al., 1972). Chrome spinel rock varieties sharply predominate, with a minor proportion of pyrope ultramafics and a complete absence of ilmenite ultramafic rocks. Rocks with typical porphyroclastic texture occur very rarely. Mantle metasomatism (amphibolization and phlogopitization) is quite intense, however in grospydite subfacies C2 and lower-pressure rocks only. Mafics are minor, most of them being eclogite-like rocks, while typical eclogites are rare. Substrate of this type produced Alseries kimberlites. Its relicts (fragments) are most representatively manifested in kimberlite pipes of the Zolotitsky pipe cluster (the Lomonosov deposit): the Lomonosovskaya, Pionerskaya, Karpinsky-1, Karpinsky-2, Arkhangelskaya and Snegurochka pipes.

The heterogeneous "eclogite-peridotite" substrate Type 2 is further subdivided into two subtypes:

\section{A. Essentially "eclogite-peridotite" substrate.}

The set of mantle rocks is very diversified. Ultramafics of the Mg-Al magmatic series (Marakushev, 1984) are sharply dominated by pyrope rock varieties (from diamond-pyrope facies $\mathrm{D}$ to spinel-pyrope subfacies C1), with a few chrome spinel ultramafic rock fragments and a complete absence of any spinel ultramafics of the spinel-pyroxene depth facies B. Pyrope peridotites of the grospydite subfacies C2 exhibit intense mantle metasomatism (amphibolization). Cataclastic rocks are minor, with rare garnetized orthopyroxenites related to disintegration. Unlike the "dunite" substrate, the essentially "eclogite-peridotite" substrate shows a great abundance of ilmenitic and pyrope-ilmenite olivinites, peridotites, pyroxenites (not uncommonly, phlogopitebearing), and $\mathrm{Fe}-\mathrm{Mg}$ and $\mathrm{Mg}$-eclogites. In addition, eclogite-like rocks and granulites are also abundant. Mantle substrate of this type produced Fe-Ti series kimberlites. Its relicts are best manifested in kimberline pipes An-688, An-751, An-748 and An-734 of the Pachuga pipe fields.

\section{B. The "eclogite-clinopyroxenite-peridotite" substrate.}

The set of mantle rocks is very diversified. The Mg-Al magmatic series ultramafics are sharply dominated by pyrope rock varieties (from diamond-pyrope depth facies D to spinel-pyrope subfacies C1), namely, pyrope dunites, lherzolites and clinopyroxenites. Pyrope-free chrome spinel peridotites and low-pressure spinel peridotites (so typical of the "dunite" substrate) are rare. Ilmenite (more rarely, pyrope-ilmenite) olivinites, peridotites and pyroxenites are quite abundant. Very abundant are bimineral F-Mg eclogites and eclogite-like rocks and granulites. Cataclastic rocks are rare. In contrast to the above described substrate types, the Type $2 \mathrm{~B}$ substrate is characterized by the presence of sizable amounts of diopside, chromediopside, orthopyroxene, rutile and deformed phlogopite megacrysts, and many chrome-diopsidephlogopite metasomatic rocks. In addition, no evidence of metasomatic amphibolization of peridotites, which is so typical of the Type 1 and Type $2 \mathrm{~A}$ mantle substrates, has been yet found in the Type $2 \mathrm{~B}$ substrate. This substrate obviously produced Fe-Ti series kimberlites. As of now, its relicts have been fairly identified in the Grib pipe only (See article after Sablukova et al. in this volume).

The two main types of mantle substrate (homogeneous and heterogeneous) differ drastically, primarily in that the heterogeneous substrate exhibits many and varied ilmenite ultramafic rock occurrences which might represent some deep-seated intrusive rocks of the Fe-Ti series (Marakushev, 1984) intruded into different upper mantle levels. Based on unambiguous geochemical features of the Fe-Ti series kimberlites that formed as a result of melting of the heterogeneous mantle substrate (primarily, on the greater than $9 \mathrm{ppm}$ Ta content of the autoliths, which indicates the presence of ilmenite ultramafics in melting substrate rocks), one can confidently map this substrate type in the central part of the Zimny Bereg area and the homogeneous substrate in the marginal zones of this district (Figure 1). This pattern may reflect the geometry of the intruded mantle diapir. In addition, two types differ in composition of rocks making up the uppermost depth section horizons. The homogeneous substrate type in characterized by certain abundance of amphibolites and garnet amphibolites, whereas the upper parts of the both heterogeneous substrate subtype ections are sharply dominated by eclogite-like rocks and granulites. The distribution of the different deep-seated rock types in the depth section of the Zimny Bereg area is shown in Figure 2.

In the homogeneous substrate and in the "eclogiteperidotite" subtype of the heterogeneous substrate, partial metasomatic replacement of individual minerals (amphibole and phlogopite) shows in the ultramafic rock matrix unclear spots, without any break in rock continuity (duffusion-type metasomatism). In the "eclogite-clinopyroxenite-peridotite" subtype of the heterogeneous substrate, this replacement pattern involves phlogopite only (amphibole lacks); however, this substrate abounds with continuous phlogopiteclinopyroxene metasomatites which may form separate bodies, such as veins and segregations (infiltration-type metasomatism). The water-alkali (K-Na) mantle metasomatism can be detected both directly, from the 




Figure 2. Schematic section on line A-B of mantle substrate of the Zimny Bereg, made according to studying deep-seated inclusions and features of volcanic rock compositions. Above show character of distribution of tantalum in autoliths from volcanic rocks of the Zimny Bereg by section Â-Á. 1 - usual igneous and metamorphic rocks of the upper crust; 2 - amphibolites and garnet amphibolites; 3 -gabbroids; 4 - granulites; 5 -eclogite-like rocks; 6 - eclogites; 7 - clinopyroxenites and websterites; 8 - spinel ultramafics; 9 - granatized spinel ultramafics; 10 - chrome spinel ultramafics; 11 - pyrope ultramafics; 12 - ilmenite ultramafics; 13 - phlogopite-clinopyroxene metasomatites; 14 - zones of the metasomatic amphibolization of mantle rocks. 
immediately observable amphibolization of mantle ultramafics (in pipes of the Zolotitsa and Pachuga pipe fields), and from indirect evidence, such as the presence of melilite (and, more rarely, and in lesser amounts, nepheline) in all Al series kimberlites and in most Fe-Ti series kimberlite rocks (Sablukov et al., 2002). This allows us to outline the zone of water-alkali (K-Na) mantle metasomatism, which covers much of the Zimny Bereg area (Figure 1). In this zone, kimberlites of the both series are characterized by a predominance of rounded (dissolved) "Uralian-type" diamonds, which may be due to dissolving action of $\mathrm{Na}$-enriched kimberlitic melts. The only exception is the Grib pipe, where deep-seated rock xenoliths show no evidence of mantle amphibolization, whereas clinopyroxenephlogopite metasomatites are abundant, which allows us to outline a zone of water-calc-alkali (K-Ca) mantle metasomatism in the Zimny Bereg area and, therewith, to identify the peculiar "eclogite-clinopyroxeniteperidotite" subtype (2B) of local heterogeneous mantle substrate. It is quite probable that the peculiar type of mantle metasomatism and the absence of any ingress of the highly active dissolving sodic component into the kimberlitic melt are responsible for the survival of most diamond in its most typical, flat-faced octahedral from in the Grib pipe.

\section{Compositional peculiarities of the homogeneous "dunite" substrate rocks}

Whereas the heterogeneous "eclogite-peridotite" and "eclogite-clinopyroxenite-peridotite" mantle substrates of the Zimny Bereg kimberlite district are comprised generally of those mantle rocks that are also common in other kimberlite districts worldwide, mantle rocks of the homogeneous "dunite" substrate of the Zimny Bereg area stand out because of being extremely depleted of basaltic component, which is manifested in their almost purely olivinic composition and very low pyrope and pyroxene contents as compared to similar mantle rocks from other regions worldwide (Yakutia, South Africa and others). The homogeneous "dunite" substrate of Zimny Bereg may be considered an example, or a lithotype, of "depleted mantle", and its geochemical characteristics, when calculated as average composition parameters for xenoliths of the most abundant mantle rocks, would be of great petrological importance along with the average composition of "primitive mantle". In particular, for all kimberlite types, even for the geochemically enriched Fe-Ti series kimberlites, the initial points of compositional trends lie precisely within the field of calculated "depleted" mantle average composition rather than in the field of average "primitive" (or "fertile") mantle composition. The average composition calculated for 30 ultramafic rock xenoliths from kimberlites from the Zolotitsa field pipes (based on chemical and INA analyses), which may be considered to a first approximation as average "depleted mantle" composition, is the following: $\mathrm{SiO}_{2}$ 43.06; $\mathrm{TiO}_{2}-0.11 ; \mathrm{Al}_{2} \mathrm{O}_{3}-1.46 ; \mathrm{FeO}_{\text {ot }}-6.37 ; \mathrm{MnO}-$ $0.27 ; \mathrm{MgO}-33.26 ; \mathrm{CaO}-0.95 ; \mathrm{Na}_{2} \mathrm{O}-0.44 ; \mathrm{K}_{2} \mathrm{O}-$ $0.24 ; \mathrm{P}_{2} \mathrm{O}_{5}-0.09$ (wt. \%); $\mathrm{Ni}-3040 ; \mathrm{Cr}-2425 ; \mathrm{Co}-$ 147 ; $\mathrm{Sc}-6.3$; Hf $-0.65 ; \mathrm{Ta}-0.54 ; \mathrm{Th}-0.41 ; \mathrm{U}-0.67$ (ppm).

This study was supported by the Russian Foundation for Basic Research, grant 01-05-64257.

\section{REFERENCES}

Ilupin I.P. 1983. Tantalum in ilmenites from kimberlites and from kimberlite matrix of the Siberian Province. Dokl. Akad. Nauk SSSR 272, 272-274 (in Russian).

Marakushev A.A. 1984. Peridotite nodules in kimberlites and basalts as indicators of deep litosphere structure; Proc. $27^{\text {th }}$ IGC, Petrol., Sect. S.09, vol.9, Moscow, Nauka, p.153-161 (in Russian).

Sablukov S.M. 1987. Age of the ultramafic rock pipes, Trudy TsNIGRI, 218, 24-27 (in Russian).

Sablukov S.M. 1990. Petrochemical series of the kimberlite rocks. Dokl. Akad. Nauk SSSR 313(4), 935-939 (in Russian).

Sablukov, S.M., Sablukova, L.I. and Shavirina, M.V. 2000. Mantle xenoliths in the Zimny Bereg kimberlite deposits of rounded diamonds, Arkhangelsk diamondiferous province. Petrologiya, 8(5), 466-494 (in Russian).

Sablukov, S.M., Sablukova, L.I. and Verichev, E.M. 2002. Essential types of mantle substrate in the Zimny Bereg region in connection with the formation of kimberlite hosting rounded and flat-faced diamonds. In: Proceedings of Int. Workshop "Deep-seated magmatism, magmatic sources and the problem of plumes", Vladivostok, Russia, p. 185-202 (in Russian).

Sergeeva, O.S. 2000. Morphological peculiarity of diamonds from Grib pipe. In: Material on geology and mineral deposits of Arkhangelsk district, Arkhangelsk, 2000, pp.97-102 (in Russian).

Verichev, E.M., Sablukov S.M., Sablukova L.I et al. 1999. A new type of diamondiferous kimberlites of the Zimny Bereg, Arkhangelsk diamondiferous province. Dokl. Ross. Akad. Nauk. 368(2), 226-229 (in Russian).

Sobolev, V.S, Dobretsov, N.L. and Sobolev, N.V. 1972. Classification of the deep-seated xenoliths and types of the upper mantle. Geol. and Geoph.12, 37-42 (in Russian).

\begin{tabular}{llll}
\hline Contact: & S.M. Sablukov, TsNIGRI, Varshavskoe & shosse, \\
129b, Moscow, Russia, & 117545, & E-mail: \\
S.Sablukov@g23.relcom.ru & & &
\end{tabular}

